\title{
Opening the Purple Wardrobe: A Psychoanalytic Approach to the Poetry of Richard Crashaw (1613-1649)
}

\author{
Bill Phillips \\ Universitat de Barcelona
}

\begin{abstract}
Richard Crashaw is often considered the odd man out in Metaphysical poetry. He is condemned for being the "most European", or "Baroque", and although he is not unusual in writing religious poetry, he is unique in his devotion to the Virgin Mary, and for his obsession with bodily fluids. This essay explores Crashaw's reasons for adoring the mother-figure and anathematizing the father, by means of a brief psychoanalytic appraisal of his life and work, and shows why so many critics have felt uncomfortable with lines like: "To see one blended in one flood,/The mother's milk, the children's blood."
\end{abstract}

According to Paul Parrish in The Muses Common-Weale, Crashaw's poetry "is seen as too obsessed with a limited range of experiences and images, especially of liquefaction water, milk, blood - and thus as unusual, strange or grotesque" (152) and in The Pelican Guide to English Literature, vol. 3, we are told that the "reader may be faintly repelled" (Enright, 202) by the poem "Upon the Infant Martyrs":

To see both blended in one flood, The Mothers' Milk, the Children's blood, Makes me doubt if Heaven will gather, Roses hence, or Lilies rather (Crashaw, 51).

Apart from being slightly grotesque, such reactions are also attributed to the ultramontane nature of his poetry: it is considered too baroque, too European; and most tellingly, "not exactly English" (Enright, 202), and I shall show that this foreignness, or 
otherness, is crucial to an understanding of Crashaw's obsession with liquids, with mother and child, and ultimately, to an understanding of the poetry itself.

For Crashaw, as a Roman Catholic, the Virgin Mary is a central figure of devotion, and is frequently the subject of his praise. One of his better known poems is "The Tear," wept by "Sweet Mary" and compared variously to a diamond, a star, a pearl, rain and wine. The sensual nature of Crashaw's relationship with the Virgin is apparent in the fourth stanza when the tear becomes a pearl:

Such a pearl as this is,

(Slipp'd from Aurora's dewy breast)

The rose-bud's sweet lip kisses;

And such the rose itself, when vex'd

With ungentle flames, does shed,

Sweating in too warm a bed (Crashaw, 29).

The comparison of one of Mary's tears with a pearl slipping "from Aurora's dewy breast" is relevant, since Aurora's son, Memnon, was killed by Achilles, and in recognition of her loss, Night filled the sky with clouds, darkening the day, just as there was "a darkness over all the earth" (Luke 23:44), when Jesus died on the cross. According to myth, dew drops are Aurora's tears, still falling in memory of her son (Grimal, 267). This concordance of loss, darkness and tears is not, however, the whole story, for Aurora, under the name of Eos, was more famous, or rather, notorious, for her insatiable sexual appetite, to the extent that a jealous Aphrodite turned her into a nymphomaniac after an affair with Ares (Grimal, 137).

The rose, too, is not a symbol of motherly love in either Classical Greece, or in the seventeenth century, but rather of sensuality and mortal passions. Sappho, indeed, refers to Eos and roses together: "Eos, the dawn - whose arms are roses" (Sappho, 31), while both Ben Jonson's "Drink to me, only, with thine eyes" and Edmund Waller's "Go lovely rose" employ the rose as a symbol of carpe diem and secular love. (Jonson, 102; Waller, 394). Crashaw's rose, "Vex'd/ With ungentle flames" is clearly within the same tradition, and if the combination of the incontinent Eos and the flaming rose are not enough to suggest that Crashaw's devotion to the Virgin is nothing if not profoundly sexual, we have the image of "sweating in too warm a bed" to confirm our impression.

But is not the Virgin Mary the ultimate symbol of motherhood, and pure asexual motherhood at that? The short poem "Blessed be the paps which Thou hast sucked" (Crashaw, 46) suggests even more strongly, that she is not:

Suppose he had been tabled at thy teats,

Thy hunger feels not what He eats;

He'll have his teat ere long, a bloody one,

The mother then must suck the son.

The extraordinary image of the mother sucking the son, rather gruesome even for Crashaw's contemporaries, cannot be anything but Freudian for a twentieth century 
readership with the poet fantasizing, in Oedipus complex fashion, about a sexual relationship between mother and son. A conventional Christian reading of the poem would surely interpret the sucking of Jesus's bloody teat by his mother as a reference to the wound caused by the spear thrust into his side by a soldier as he hung on the cross, and then commemorated in the eucharist: "The blood of our Lord Jesus Christ which was shed for thee, preserve thy body and soul unto everlasting life. Drink this in remembrance that Christ's Blood was shed for thee, and be thankful." (from The Communion). Yet the image is contrived even by the standards of a metaphysical conceit.

If Crashaw's treatment of Mary is fundamentally Oedipal; that he sees her as a mother figure, then his obsession with liquefaction makes sense. Freud identifies two organizations of pregenital sexual life, the first of which is oral, where "sexual activity has not yet been separated from the ingestion of food" (On Sexuality, 116-7). The oral stage is associated with the ingestion of milk, with drinking, and with liquids in general, and as Freud comments, when the erotogenic significance of the labial region persists, children may grow up to be "epicures in kissing" and, if males, "will have a powerful motive for drinking and smoking" (98-9). In this context, the poem "Blessed be the paps which Thou hast sucked" quite clearly indicates sexual fantasy, particulary when it is remembered that Freud also described oral pregenital sexual organization as "cannibalistic" (72) with the child eating the mother, and in this poem, the mother eating her son.

But why should Crashaw be so concerned with a mother figure? According to Jacques Lacan, one of Freud's greatest insights came through the observation of his grandson, who threw a cotton reel out of his cot, shouting "Fort", or "Gone". He then reeled it in with the cry of "Da", or "Here". To Freud, and later, Lacan, this game represented the child's control of his mother's presence and absence through language. The first part of the game symbolically kills the mother; in Lacan's words: "the symbol manifests itself first of all as the murder of the thing, and this death constitutes in the subject the eternalization of his desire" (Lacan, 104). The satisfaction of need for the mother (or the Other, for Lacan) by language, turns that need into a never ending demand, hence the eternalization of desire. But what if the cotton should break and can never be reeled in; if the mother really dies? Then the need for the mother becomes all the more desirable for its very unavailability, and this is what happened to Crashaw. His mother died, probably in 1619, when Crashaw was six, still young enough to retain an idealized perception of her, but not yet ready to question her "unimpeachable moral purity" (Freud. On Sexuality, 237) through the simultaneous discovery of parental sex and the existence of prostitution, which Freud claims occurs in pre-puberty. In Crashaw's case, this loss was compounded by the fact that his father remarried in 1619 , to Elizabeth, who died shortly after, in childbirth, and was praised in her funeral sermon for the "singular motherly affection" (Beeching, xxii) that she showed to Richard.

But what of Crashaw's father, William, a man who "was especially learned and acrimonious in the Roman controversy, and contributed to it some dozen books and pamphlets with full-blooded titles in the manner of the time,"(Beeching, xxi) a man described by D.J. Enright as "a Puritan rector for whom the Pope was Antichrist"(Enright, 201)? We learn from Freud and Lacan that it is the authority of the father, indeed the Name-of-the-Father, which upholds the patriarchy, and prevents the destruction of 
patriarchal society through incestuous relationships between mother and son. The death, even murder, of the father may be wished for by the son, in his desire for the mother, but, according to Lacan "this murder is the fruitful moment of debt through which the subject binds himself for life to the Law, the symbolic father is, in so far as he signifies this Law, the dead Father" (Lacan, 199), and "[t]he real father's authority is never so strong as in his absence or death" (Grosz, 68).

Crashaw's father died when he was thirteen, and the poet went on to study at Cambridge, where he came under the influence of High Anglican royalists, and by 1646, following ejection from Cambridge for supporting the king, he was met by Abraham Cowley in Paris and introduced to Queen Henrietta Maria. His conversion to Roman Catholicism occurred at this time, and he produced quantities of devotional poetry, much of which was published in 1646 under the title Steps to the Temple. All of this would appear to contradict Freud and Lacan, for whom the Law-of-the-Father, particularly a dead father, ought to have prevailed, and a conversion to Catholicism is surely the last thing that William Crashaw would have permitted his son.

Nevertheless, the substitution of the father for religion is not in the least unusual, and Freud's "Totem and Taboo" claims that it is the guilt felt by the son for the real (or imagined) murder of the father that gave rise to patriarchal religion in the first place. Crashaw's case may be slightly more complicated, as any individual case invariably is when compared to a generalised model. On the one hand he may have believed that his father was responsible for the death of his mother. We do not know the cause of her death, but if it was in childbirth - extremely likely in the seventeenth century - and the death of his stepmother was certainly for that reason (Beeching, $x x i$ ), then he may well have believed that his father was the cause of their deaths. And on the other hand, we have the interesting example of Christoph Haizmann. Freud published an account, and analysis of Haizmann in 1923 under the title "A Seventeenth-Century Demonological Neurosis." According to the story, Haizmann was a painter who, after his father's death, fell into a state of melancholia which prevented him from working. He sold his soul to the devil in exchange for the latter agreeing to replace his lost father for nine years, and was able to return to work. The reasons for substituting his father, whom he loved, for the devil, are explained by Freud in the following way:

The contradictions in the original nature of God are [...] a reflection of the ambivalence which governs the relation of the individual to his personal father. If the benevolent and righteous God is a substitute for his father, it is not to be wondered at that his hostile attitude to his father, too, which is one of hating and fearing him and of making complaints against him, should have come to expression in the creation of Satan. Thus the father, it seems, is the individual prototype of both God and the Devil ("A Seventeenth Century Demonological Neurosis," 401).

It should come as no surprise, then, that Crashaw took up a faith ruled by a man that his father had identified as the Anti-Christ. It will also come as no surprise, that in Crashaw's poetry, with the exception of Jesus, the Son of God, men are devilish and women are saints or virgins. And the exception of Jesus is simply explained in "Totem and 
Taboo" where Freud claims that the Son of God, is in fact the symbol of atonement for that great, Original $\mathrm{Sin}$, the murder of the father by the son, through his own, sacrificial, death.

This brings us back to the first poem I mentioned, "Upon the Infant Martyrs." These babies, killed by the patriarchal Herod, combine the love of the mother, identified through her milk, with their own innocent deaths; the blood and milk are mingled and glorified in heaven as Roses and Lilies. Crashaw was rather obsessed with the murder of the Holy Innocents, writing two poems entitled "Upon the Infant Martyrs;" the other poem with this title underlines the heavenly nature of suckling, though managing to sound rather like an advertisement for the Milk Marketing Board at the same time:

Go, smiling souls, your new-built cages break, In heaven you'll learn to sing ere here to speak:

Nor let the milky fonts, that bathe your thirst,

Be your delay;

The place that calls you hence is, at the worst, Milk all the way. (Crashaw, 50)

One of his longest poems, "Sospetto d'Herode," is on the same theme; indeed, it may be seen as his equivalent to Milton's Paradise Lost, though published nearly twenty years earlier, since it begins with a description of Satan, in the underworld, contemplating the undoing of his former master's work. But it is Herod, rather than Eve, who is the object of the fiend's attentions, and the murder of the infant Jesus, rather than the corruption of humanity, which he seeks. And it is here that Crashaw once again shows his sympathy for women, and mothers in particular. Sixteen hundred years of misogyny may have inclined the church to blame women for the world's evils, but for Crashaw, in his poetry, it is men, and patriarchal men at that, who form a rival, diabolical trinity: Satan, Herod and Pontius Pilate.

Women, and not only the Virgin Mary, but also Saint Teresa, Saint Mary Magdalene (The Weeper), and the Queen, are the embodiment of all virtues, purity and salvation. Paul Parrish concludes that his poetry reveals "his deep allegiance to feminine virtues. In the public world of religious controversy and political warfare, masculine qualities are, in Crashaw's hands, minimized and subdued; in the imaginative world of saints and idealized feminine figures these same qualities function as images - forceful, original, provocative and disturbing" (Parrish, 162). And here also, I shall conclude. Crashaw's poetry is indeed provocative and disturbing, as well as unusual, strange and foreign, and for reasons that I hope to have made obvious: it centres on the (M)Other.

\section{Works Cited}

Authorised King James Version of The Bible. Londion: Lutterworth Press, n.d. 
Beeching, Canon. Introduction.The Poems of Richard Crashaw. By Crashaw. Ed. J.R. Tutin. London: Routledge, n.d.

Crashaw, R. The Poems of Richard Crashaw. Ed. J.R. Tutin. London: Routledge, n.d.

Enright, D.J. "George Herbert and the Devotional Poets" The Pelican Guide to English Literature 3. Ed. Boris Ford. Harmondsworth: Penguin, 1982.

Freud, S. On Sexuality. The Penguin Freud Library 7. 1953. Ed. Angela Richards. Harmondsworth: Penguin, 1991. "A Seventeenth-Century Demonological Neurosis." The Penguin Freud Library 14. 1953. Ed. Angela Richards. Harmondsworth: Penguin, 1988. . "Totem and Taboo" The Freud Reader. Ed. Peter Gay. London: Vintage, 1995.

Grimal, P. The Concise Dictionary of Classical Mythology. Ed. Stephen Kershaw. Oxford: Basil Blackwell, 1990.

Grosz, E. Jacques Lacan: A Feminist Introduction. London: Routledge, 1990.

Jonson, Ben. "Drink to Me, Only, with Thine Eyes" Epigrams and the Forest. Ed. Richard Dutton. Manchester: Carcanet, 1984.

Lacan, J. Écrits: A Selection Trans. Alan Sheridan. Bristol: Routledge, 1989.

Parrish, P.A. "Crashaw's Life and Art" "The Muses Common-Weale" Poetry and Politics in the Seventeenth Century. Eds. Claude J. Summers and Ted-Larry Pebworth. Columbia: University of Missouri Press, 1988.

Sappho Poems and Fragments Trans, and Ed. J. Balmer. London: Brilliance Books, 1984. The Book of Common Prayer. London: Eyre \& Spottiswoode, Ltd. c.1918.

Waller, E. "Go Lovely Rose" The New Oxford Book of Seventeenth Century Verse. Ed. Alastair Fowler. Oxford: OUP, 1992. 